\begin{tabular}{|c|c|c|}
\hline \multirow{2}{*}{ MIMBAR HUKUM } & \multirow{2}{*}{$\begin{array}{l}\text { Tittle } \\
\text { Author }\end{array}$} & \multirow{2}{*}{$\begin{array}{l}\text { : IMPROVING OUTSOURCING SYSTEM IN INDONESIA: } \\
\text { FIXING THE GAP OF LABOUR REGULATION } \\
\text { : Nabiyla Rista Izzati }\end{array}$} \\
\hline & & \\
\hline DOI & \multicolumn{2}{|c|}{ : http://doi.org/10.22146/jmh.28372 } \\
\hline Publisher & \multicolumn{2}{|c|}{ : Faculty of Law Universitas Gadjah Mada } \\
\hline URL & \multicolumn{2}{|c|}{ : jurnal.ugm.ac.id/jmh } \\
\hline E Issn & \multicolumn{2}{|l|}{ : 2443-0994 } \\
\hline P Issn & \multicolumn{2}{|l|}{ :0852-100x } \\
\hline
\end{tabular}




\title{
IMPROVING OUTSOURCING SYSTEM IN INDONESIA: FIXING THE GAP OF LABOUR REGULATION*
}

\author{
Nabiyla Risfa Izzati** \\ Labour Law Department, Faculty of Law, Universitas Gadjah Mada \\ Jalan Sosio Yustisia No. 1 Bulaksumur, Sleman, D.I.Yogyakarta 55281
}

\begin{abstract}
Outsourcing is always been one crucial issues in Indonesian labour law. Since this system legalized by Law Number 13 Year 2003 on Manpower, there has been a lot of resistance from workers and unions, because outsourcing system is considered detrimental to the position of workers. However, does abolishing outsourcing system the best solution? This research will trace the history of Indonesia's outsourcing system, the advantages and disadvantages of this system, and some possible ways to improve the system. By improving outsourcing system within the legal framework and its implementation, it is not impossible that this system will bring benefits to both workers and employers.
\end{abstract}

Keywords: outsourcing, labour law, manpower.

\section{Intisari}

Outsourcing atau alih daya merupakan salah satu permasalahan yang krusial dalam ranah hukum ketenagakerjaan di Indonesia. Sejak awal model hubungan kerja ini dilegalkan oleh Undang-Undang Nomor 13 Tahun 2003 tentang Ketenagakerjaan, muncul banyak perlawanan dan resistensi dari kalangan pekerja dan serikat pekerja karena dianggap merugikan posisi pekerja. Namun, apakah menghapuskan sistem outsourcing merupakan solusi? Penelitian ini akan menelusuri sejarah sistem outsourcing Indonesia, kelamahan dan kelebihan sistem ini, serta cara yang mungkin dilakukan untuk memperbaiki sistem ini. Dengan memperbaiki sistem outsourcing dalam kerangka hukum dan pelaksanaan, bukan tidak mungkin sistem ini justru membawa kemanfaatan bagi pekerja maupun pengusaha.

Kata Kunci: outsourcing, alih daya, hukum ketenagakerjaan, buruh.

\section{Pokok Muatan}

A. Research Background 530

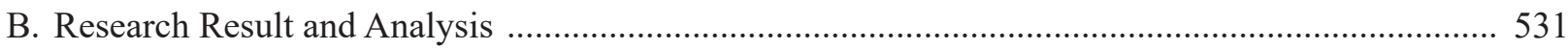

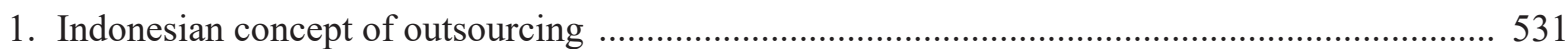

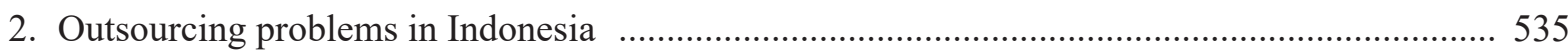



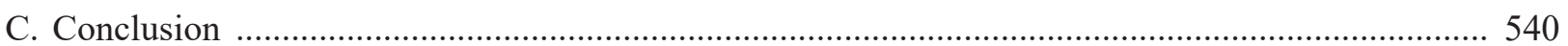

This article is processed from the writer's master thesis, titled "Comparative Study of Outsourcing in Indonesia: What Can Indonesia Learn from Temporary Agency Work in European Union”, supervised by Prof. dr. Barend Barentsen, Leiden University, Leiden Law School, 2015. *** Correspondence address: nabiylarisfa@mail.ugm.ac.id. 


\section{A. Research Background}

The term 'outsourcing' commonly refers to a practise by companies, by which they delegate some part of their work to be performed by a subcontractor company, rather than completing it internally. Maurice F. Greaver describe outsourcing in a broader sense as something that is beyond just contracting a job for someone outside a company (outside provider). ${ }^{1}$ She states that outsourcing is the act of transferring some of the company's recurring internal activities and decision right to the outside provider, as set forth in the contract. ${ }^{2}$ Since the activities are recurring and a contract is used, outsourcing goes beyond the use of consultants. ${ }^{3}$ As a matter of practice, not only are the activities transferred, but the factors of production and decision are often shifted as well. ${ }^{4}$ Factors of production comprise the resources that make activities occur and include people, facilities, equipment and technology, and other assets. Decision right is the responsibility for making decisions over certain elements of the activities transferred." 5

Outsourcing systems raise new types of employment relationship: A triangular relationship. In this type of situation, the employee of the subcontractor company is temporarily assigned to the user company to perform certain temporary work. This type of employee is usually called an outsourcing worker. The characteristic of outsourcing workers is that they only have employment relationship with the subcontractor company, but with the user company. However, they have an obligation to perform work for the user company. In addition, outsourcing workers are usually contracted through fixed term employment agreements, which put the workers in a temporary employment relationship.

The outsourcing system has become a very popular global trend as it provides solutions for dynamic and fast moving businesses. The user company can respond quickly and effectively to short-term increases in the volume of work, like seasonal work, temporary sales growth, or project work, because outsourcing gives more flexibility to it to hire and fire employees. As for the employee, outsourcing usually serves as a 'stepping stone', raising the possibility to find a permanent employment for the workers while they are doing the outsourcing job. ${ }^{6}$

In many countries, such as India, China, or the Philippines, the outsourcing business is already a common practice. Indonesia has also become a part of this global trend. Outsourcing work has been a prominent issue in Indonesian labour law in the past few decades. Since the issuance of Law Number 13 of 2003 concerning Manpower Affairs, which listed outsourcing as a type of work agreement, the issue of outsourcing has increasingly gained in prominence. As per Article 64 of this regulation, 'an enterprise may subcontract part of its work to another enterprise under a written agreement of contract of work or a written agreement for the provision of worker/labour.' ${ }^{7}$ Thus, this provision has opened the door for outsourcing work in Indonesia.

Following this, the Minister of Manpower and Transmigration in Indonesia enacted Ministerial Regulation Number 19 of 2012 concerning the requirements for outsourcing a supply of labour and subcontracting of services. This regulation further pertains to the rights and obligations of each stakeholder in the outsourcing system. The concept of outsourcing in Indonesia basically refers to two types of conditions: First, the user company delegates part of its work to be performed by subcontractor companies, and second, the user company hires workers on a contractual basis

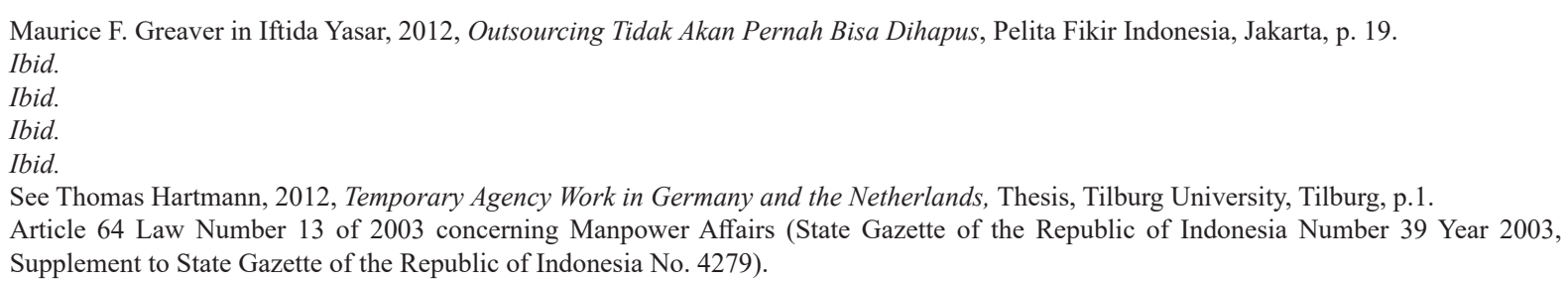


through a labour provider. Both types of delegation are considered as 'outsourcing'.

In Indonesia, the outsourcing system has given employment to 16 million people, or about $40 \%$ of Indonesia's total workforce. Thus, it has created a multiplier effect by boosting consumption and production levels in Indonesia's economy. ${ }^{9}$ Nevertheless, outsourcing is still a hot-button issue in the context of Indonesian labour law. Over the years, there has been a lot of resistance from Indonesian workers regarding the implementation of the outsourcing system. Labour unions in Indonesia continuously demand that the government must eliminate the outsourcing system, since this practice is considered to be detrimental by the workers. The main problems mostly relate to the workers' rights that are less protected in the outsourcing system, aggravated with high abuse in the practice.

On the one hand, the outsourced workers' demand that their rights should be given more protection is fair and justified. The perception of outsourcing by many Indonesians, especially workers, is negative as the government has not been forthcoming in implementing outsourcing regulations. ${ }^{10}$ Furthermore, the outsourcing regulations in Indonesia have several vague and unclear provisions, and they are also very limited when it comes to protecting the rights of outsourcing workers.

However, elimination of outsourcing will not solve the key issue of labour problem in Indonesia. Even worse, it may lead to a new problem of unemployment. Therefore, instead of abolishing outsourcing that could result in the layoff of millions of workers, the government may improve the outsourcing system so that the outsourced workers will have more protection, and may enjoy equal rights as those of the permanent workers in the user companies.

There are three main questions that tried to be answered in this research, which are: (1) how is Indonesian regulation lay of the concept of outsourcing; (2) what is the current problem in Indonesian outsourcing system; and (3) how to improve the outsourcing system in Indonesia so it will be beneficial of both parties.

\section{B. Research Result and Analysis \\ 1. Indonesian concept of outsourcing}

\section{a. History of outsourcing in Indonesia}

The basic concept of outsourcing in Indonesia is a situation where user companies delegate part of their work to be performed by subcontractor companies or labour suppliers. The work will then be done by the employees of the subcontractor companies/ labour suppliers, making it a triangular relationship between user companies, subcontractor companies/labour suppliers, and the employees. ${ }^{11}$

The concept of outsourcing has existed for a long time in Indonesian labour law. Article $1601 \mathrm{~b}$ of the Indonesian Civil Code recognizes the basic concept of outsourcing under the term 'contract for work', which means 'the agreement by which one party, the contractor, binds himself to the other party, the client, to carry out specific tasks for specific price'. ${ }^{12}$ The concept of 'contract for work' is different with that of the regular 'labour agreement' in Article 1601a, which defines it as 'an agreement in which one party, the employee, agrees to render his services to the other party, the employer, for a specific term in return for remuneration'. ${ }^{13}$

However, 'contract for work' as defined

Article 65 and 66 Law Number 13 of 2003 concerning Manpower Affairs(State Gazette of the Republic of Indonesia Number 39 Year 2003 , Supplement to State Gazette of the Republic of Indonesia No. 4279).

See: Sofjan Wanandi, "Global Business Guide Indonesia: Solutions for the Outsourcing System in Indonesia", http://www.gbgindonesia.com/ en/main/partners_updates/apindo/solutions_for_the_outsourcing_system_in_indonesia.php, accessed on 5 October 2017.

Ibid.

Iftida Yasar, Op. cit., p. 17.

Article 1601b Indonesian Civil Code.

Article 1601a Indonesian Civil Code. 
in Article $1601 \mathrm{~b}$ cannot be fully categorized as outsourcing since it only covers the relationship between the subcontractor companies/labour suppliers with the user companies, but not with the employees. What is known as outsourcing nowadays first emerged in the form of 'sub-contract work' as stipulated in the Ministry of Trade Decree Number 264/Kp/1989 relating to Subcontract Work.

A few years later, the Ministry of Trade issued Decree Number 135/KP/VI/1993 concerning Export and Import of Goods in Certain Zone. Both provisions stipulate that garment companies operating in export processing zones are allowed to hand out some of their work to other companies so as to decrease time and production cost in order to meet the export market demand. ${ }^{14}$ Therefore, the implementation of the outsourcing system in Indonesia was initially limited to specific production sectors.

Outsourcing system began to be incorporated into Indonesian labour policy with the Ministry of Manpower's Decree Number SE-08/MEN/1990 that laid the regulations for the user company's responsibility for the workers' protection and welfare. The decree recognizes that most of the time, there is a striking difference in the protection and welfare policies for the workers in the user company and in the subcontract company. Thus, the regulation makes it obligatory for user companies to conduct training and make some efforts to ensure that the protection and welfare of outsourced workers is the same as that of the permanent workers. ${ }^{15}$ It means that the responsibility of the outsourced workers lies with the user company.
However, this obligation seemed to be too burdensome for user companies. The government responded to the complaints with the issuance of Ministry of Manpower Regulation Number Per-02/Men/1993 concerning temporary employment agreement. The regulation shifted the responsibility for the protection and welfare of workers to the subcontract companies. ${ }^{16}$

Table 1.

\section{Comparison between the previous and current outsourcing regulations}

\begin{tabular}{|c|c|}
\hline $\begin{array}{l}\text { Ministry of Trade Decree } \\
\text { Number 135/KP/VI/1993 }\end{array}$ & Law Number 13 of 2013 \\
\hline $\begin{array}{l}\text { Can only be done if the capacity } \\
\text { of user company is insufficient } \\
\text { to meet the demand and deadline } \\
\text { of the export product. }\end{array}$ & There is no specific requirement. \\
\hline Only for garment company. & Applies to all types of industries. \\
\hline $\begin{array}{l}\text { The work is limited to the } \\
\text { cutting, sewing, and labelling } \\
\text { production. }\end{array}$ & $\begin{array}{l}\text { The work must not be the core } \\
\text { business of a company; the work } \\
\text { must be supplementary that is not } \\
\text { directly related to the core } \\
\text { production. }\end{array}$ \\
\hline $\begin{array}{l}\text { Only for company in the export } \\
\text { processing zone. }\end{array}$ & No restriction. \\
\hline $\begin{array}{l}\text { The time limit for each } \\
\text { subcontract work is } 60 \text { days. }\end{array}$ & $\begin{array}{l}\text { The time limit for each } \\
\text { subcontract work is two years, } \\
\text { with the possibility of one year } \\
\text { extension. }\end{array}$ \\
\hline $\begin{array}{l}\text { The concept limited to the } \\
\text { subcontract of work }\end{array}$ & $\begin{array}{l}\text { The concept applies to } \\
\text { subcontract of work as well as } \\
\text { labour supply. }\end{array}$ \\
\hline
\end{tabular}

Source : Processed by Author, 2017

This concept is reflected in the current outsourcing regulation in Indonesia: Law Number 3 of 2013 concerning Manpower. The regulation affirms that the employment relationship is between a subcontractor company and the workers, and the subcontractor company must therefore bear the total responsibility of the workers. The difference with the previous regulation is that the government has expanded the concept of outsourcing from merely being 'subcontract of work' to also cover 'labour supply' or outsourcing of workers. In addition, the

\footnotetext{
Indah Saptorini and Jafar Suryomenggolo, 2007, Kekuatan Sosial Serikat Buruh: Putaran Baru dalam Perjuangan Menolak Outsourcing, Trade Union Rights Centre, Jakarta, p. 9.

5 Ibid.

16 Ibid.
} 
government through this regulation has legalized outsourcing work in all types of businesses, and not only for garment and export production sectors as was the case initially. The following table is a comparison between the present (Law Number 13 of 2013) and the previous (Ministry of Trade Decree Number 135/KP/VI/1993) regulations.

By 2012, the outsourcing system accounted for an estimated 16 million employees or $40 \%$ of Indonesia's total workforce. ${ }^{17}$ This number shows that outsourcing has grown rapidly in the Indonesian labour system. This is understandable since outsourcing brings many advantages for the user companies, such as:

1) Enhancing the focus of the core company. If all the activities are carried out by the company itself, it will entail a lot of the company's time and energy for activities that are outside their core business. Thus, by handing over some of the jobs to outside providers, it will enable the company to be more focused on its core business activity.

2) Saving capital funds. Outsourcing system provides financial flexibility to the company.

3) Operational cost efficiency. Outsourcing can reduce operational costs for a company.

4) Diverting labour issues. With outsourcing, the user company does not need to be burdened with labour issues, such as layoff, severance, etc., since it does not have employment relationship with the outsourced workers. The subcontract company will bear all responsibilities regarding the rights of outsourced workers.

Outsourcing also brings several benefits to the government. Outsourcing system is a form of 'labour market flexibility' policy, which was adopted by the Indonesian government on the insistence of the International Monetary Fund (IMF) and the World Bank as a preferred condition for granting funds to help the country during the economic crisis in 1997. ${ }^{18}$ Labour market flexibility means that the employers have freedom to hire and fire workers at short notice and also the freedom to outsource parts or all of their business to other companies. This strategy lowers production costs, and thus attracts foreign investments. ${ }^{19}$

The introduction of the outsourcing system in Law Number 13 of 2003 was one of the ways to improve the investment climate in Indonesia. Since flexibility supposedly encourages labour mobility across sectors, the workers benefit from skills upgrading opportunities as well. The net result, it is argued, is growth in employment, and outsourcing is therefore also deemed to encourage the growth of national economy.

\section{b. Current outsourcing regulation in Indonesia}

Article 64 Law Number 13 of 2003 concerning Manpower Affairs permits outsourcing system in Indonesia and categorizes it as a type of work agreement. The provision states that 'an enterprise may subcontract part of its work to another enterprise under a written agreement of contract of work or a written agreement for the provision of worker/labour' ${ }^{20}$

Sofjan Wanandi, Loc. cit.

Indrasari Tjandraningsih, et al., 2012, Diskriminatif and Eksploitatif: Praktek Kerja Kontrak dan Outsourcing Buruh di Sektor Industri Metal di Indonesia, AKATIGA, Bandung, pp. xiv-xv.

19 Benny Hari Juliawan, "Extracting Labour From Its Owner: Private Employment Agencies and Labour Market Flexibility in Indonesia", Critical Asian Studies, 26 Februari 2010, p. 29.

20 Article 64 Law Number 13 of 2003 concerning Manpower Affairs (State Gazette of the Republic of Indonesia Number 39 Year 2003 , Supplement to State Gazette of the Republic of Indonesia No. 4279). 
One of the main characteristics of outsourcing is that an outsourced worker has an employment relationship only with the subcontractor company, and not with the user company. Article 65 (6) Law Number 13 of 2003 confirms this by stating that 'the employment relationship undertaking the work shall be regulated with written employment agreement between the subcontractor company and the workers it employs'. Thus, even though the worker is factually working with the user company, legally the employment relationship exists with the subcontractor company.

Law Number 13 of 2003 makes a distinction between 'labour providing agencies', or outsourcing agencies (Articles 64, 65, 66), and 'labour supplying agencies', whose task is to supply workers to be employed by their clients (Articles 35, 36, 37, 38). In other words, labour providing agencies employ workers to do jobs given by other firms, whereas labour supplying agencies act only as recruiting agents for other firms. ${ }^{21}$

In 2012, the Minister of Manpower and Transmigration of Indonesia enacted Ministerial Regulation Number 19 of 2012 concerning the requirements for outsourcing as supply of labour and subcontracting of services. This regulation aims to clarify the rights and obligations of the 'user company' while receiving work services, and also the relation of the 'outsourcing worker' to the 'subcontractor company' or 'labour contract agency'. Regulation Number 19 of 2012 covers two types of outsourcing: (a) business activity outsourcing (outsourcing of work); and (b) manpower outsourcing (outsourcing of workers/labour supply).

In business activity outsourcing, the subcontracted work must meet the following criteria:

1) the management and the implementation of the outsourced work must be conducted separately from the main activities of the user company;

2) the work must be performed by direct order or indirect order from the user company for the purpose of providing clarity on how to perform the work so that it is consistent with the standards of the user company;

3) the work must be supporting activities, i.e. the work is necessary to support and smoothen the implementation of the main activities as per the flow chart of the work implementation process drawn by the relevant business sector association; and

4) the work must not directly hinder the production process, i.e. the work must be an additional activity, and if not performed, the production process will still continue to be normal. ${ }^{22}$

The other type of outsourcing covered by this regulation is manpower outsourcing (labour supply). Outsourcing of labour is permitted only for 'supporting' services that are separate from the user company's core business, and may not directly affect the user's production process, including cleaning services, catering for employees, security personnel, support services in the mining and oil sectors, and employee transportation services. ${ }^{23}$

As per Article 65 (3) of Law Number 13 of 2003, outsourcing can only be done by a subcontractor company or an outsourcing agency that has the form of a legal entity. Moreover, Article 24 of Ministerial Regulation Number 19 of 2012 makes it 
obligatory for these labour providers to fulfil certain requirements, such as:

1) established in the form of a limited liability company;

2) hold a company registration certificate;

3) hold a proper business license;

4) have a proper receipt for mandatory employment report;

5) hold an operating license;

6) have a permanent office and address; and

7) have a taxpayer registration number. ${ }^{24}$

This regulation also mandates a written labour supply agreement between the user company and the labour supplier company in order to make outsourcing work legal. Then, the labour supplier has to register the signed labour supply agreement with the local office (city/municipality level) of the Ministry of Manpower and Transmigration.

The labour supplier company cannot perform its operation (supplying workers to the user company) unless the local office of the Ministry of Manpower and Transmigration issues evidence of the registration of the labour supply agreement. If the labour supply agreement is not registered and the labour supply company still conducts labour supply activities, this regulation stipulated that the relevant Provincial Office of the Ministry of Manpower and Transmigration would revoke the operation licence of the labour supply company. ${ }^{25}$

\section{Outsourcing problems in Indonesia}

There are several fundamental problems that have led to the unpopularity of outsourcing among Indonesian workers. The first problem is that the current legislation, Law Number 13 of 2003 and Ministerial Regulation Number 19 of 2012, contains some vague provisions. These prompt both employers and employees to interpret the law based on their respective interests, which has caused several problems.

One of the most problematic provisions is about the scope of outsourcing work. Article 65 (2) Law Number 13 of 2003 regulates that the work to be subcontracted must meet the requirement that 'the work can be done separately from the main or core activity of the business'. Furthermore, Article 66 (1) states that 'workers from labour suppliers must not be utilized by employers to carry out their enterprises' main activities or activities that are directly related to the production process except for auxiliary service activities or activities that are indirectly related to the production process'.

However, there is no explanation for what is meant by 'main activities or core activities of the businesses'. The user company and subcontractor company then themselves interpret what is to be categorized as core activities and what is not. Explanatory notes of Article 66 (1) only state that 'what is meant by auxiliary service activities or activities indirectly related to production process are activities outside of the core business of the enterprise. Such activities include, among others, activities associated with the provision of cleaning service, the provision of catering service, the provision of a supply of security guards, auxiliary business activities in the mining and oil sectors, and the provision of transport for workers/labourers' ${ }^{26}$

The phrase 'among others' in the explanatory notes is widely used as a justification for the user company to employ outsourced workers in another type of work, which, in its interpretation, is outside the enterprise's core business. In practice, there are many outsourced workers who are employed precisely in the main activity areas of a company, or part of the company's production process. For example, there are thousands of outsourced employees who work as tellers in a bank. The teller

\footnotetext{
Article 24 Ministerial Regulation Number 19 of 2012 concerning The Requirements of Outsourcing.

Article 21-23 Ministerial Regulation Number 19 of 2012 concerning The Requirements of Outsourcing.

Explanatory notes Article 66 (1) Law Number 13 of 2003 concerning Manpower Affairs (State Gazette of the Republic of Indonesia Number 39 Year 2003, Supplement to State Gazette of the Republic of Indonesia No. 4279).
} 
position should be categorized as a core activity in banking industries, and yet, because there are no clear provisions concerning the definition of core/ main business, this certain practice is still in vogue. ${ }^{27}$

The second problems, is related with the absence of sanction, and the lack of supervision in law. Even though Law Number 13 of 2003 and Ministerial Regulation Number 19 of 2012 seems quite rigid and try to balance the rights and protection of workers with flexibility, the absence of sanctions is a shortcoming of these provisions. There is no strict legal sanction against either the user company or the subcontractor company that violate the terms and conditions of the outsourcing system. Owing to the absence of sanctions, the enforcement of outsourcing regulations becomes less effective.

The National Office of Manpower and Transmigration Department admits that there is general lack of awareness among user companies concerning their obligations for using outsourcing system. ${ }^{28}$ For example, the obligation to submit a production process flow to determine core job and non-core job before handing over the job to a subcontract company ${ }^{29}$, is never implemented. Whereas, this obligation is important as one of the guidelines for the authorities to determine whether or not there is violation in the outsourcing practice.

Furthermore, the NationalOffice of Manpower and Transmigration states that one of the problems that make it hard to enforce outsourcing regulation is because they have limited supervisory authority, in particular to take action against companies that violate the rules..$^{30}$ Again, it also arises out of the absence of sanctions that could have had a deterrent effect. The only thing that authorities can do on the basis of the regulations is giving administrative sanction, such as written warning as stated in
Law Number 13 of 2003 concerning Manpower Affairs. ${ }^{31}$ In practice, however, the companies often ignore this, and the authorities cannot take further action since there is no legal framework to do so. The Director General of Labour Supervision in the Ministry of Manpower and Transmigration also admits to this problem. He states that the legal regulation of outsourcing system in Indonesia is still lacking and needs to be revised. ${ }^{32}$

These unclear regulation and limited supervisory from the authority caused some recurrent troubles in our outsourcing system. There are at least 3 (three) factual problems that usually appear in field, which are:

\section{a. Salary discrimination}

According to several studies conducted in Indonesia, outsourced workers who do the same type of work, with the same working hours, receive less salary than the workers of the same company do. Based on the research conduct in 2012, the average basic salary of outsourced workers is $17 \%$ lower than the permanent workers, while their total salary is $26 \%$ lower than the permanent workers. ${ }^{33}$ There are even a lot of cases where a worker's salary is less than the regional minimum wage stipulated by the government. ${ }^{34}$ This condition is exacerbated by the fact that part of the salaries of outsourcing workers will also be deducted by the subcontractor company as 'agency fee'.

Paying outsourcing workers less salary than the regional minimum wage is actually a violation of Article 90 (1) Law Number 13 of 2003. While salary discrimination between outsourced workers and permanent workers who do the same work is also a violation of Article 3 Government Regulation Number

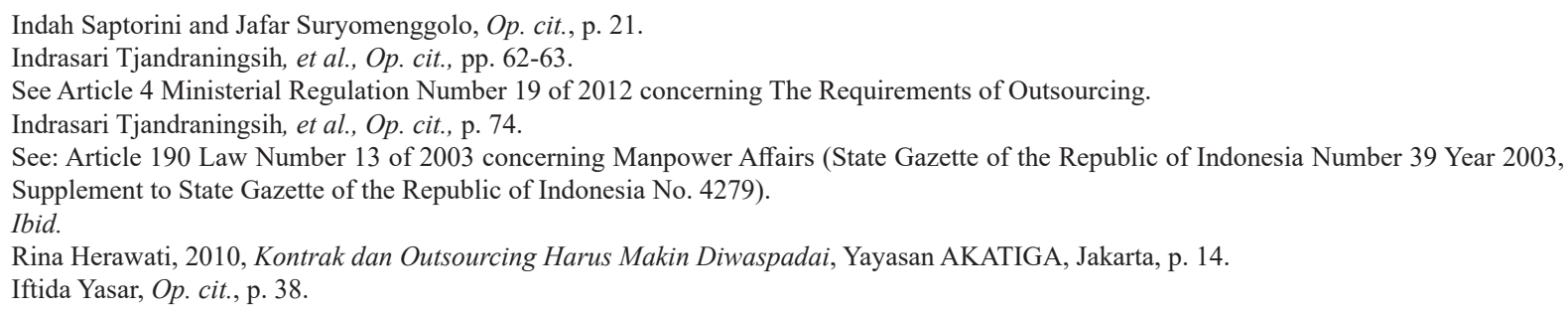


8 of 1981 concerning wage protection. However, due to the lack of supervision and protection of outsourcing workers, this practice is still commonly found in many provinces in Indonesia. ${ }^{35}$

\section{b. Rotation of workers to avoid permanent status}

Article 59 Law Number 13 of 2003 stipulates a limitation period for workers with fixed term agreement. The maximum time for an employment agreement with fixed term agreement is two years, with possibility of extension for 1 year. This means that fixed term employee who exceeds the maximum two plus one year working period must be appointed as a permanent worker. This provision is closely related with outsourcing workers because all of them are bound with fixed term work agreement with the subcontractor company. With Article 59 logic, if the outsourcing worker works for more than two plus one years in one company, their status should be transferred from fixed term employee to permanent employee. But, to whom?

From the law perspective, outsourcing workers only have legal relation with the subcontractor company, since the workers have working agreement only with subcontractor company. Thus, their status should be changed into permanent workers in their subcontractor company. On the other hand, this workers is not even doing their day to day job in the subcontractor company, hence more logical if the outsourcing workers became permanent workers in the user company. But it is also not possible because outsourcing workers and user company don't have any legal relation.

To avoid this problematic situation, the user companies as well as subcontractor companies nullify the law by regularly shifting the outsourced worker to other companies. This means that a subcontractor company will terminate the contracts with the outsourced workers by the end of two years, then they will draw up a new contract, shifting the workplace of the outsourced workers to another user company. In this way, outsourcing workers will never be appointed as permanent employees even though they have been working for many years.

The workers usually do not have the ability to oppose this situation, because their choices are rather limited: either move around different workplaces and stick with the outsourcing employment status, or lose the job. Consequently, the employment period of outsourced workers in a specific company is always for a short period of time. ${ }^{36}$

\section{c. Different rights and less protection} of outsourced workers

The following table compares the rights of permanent workers with outsourced workers based on the new Ministerial Regulation Number 19 of 2012:

Table 2.

\section{Comparison of The Rights Between Permanent Workers and Outsourced Workers}

\begin{tabular}{|lll|}
\hline \multicolumn{1}{|c|}{ Rights of Workers } & \multicolumn{2}{c|}{ Status of Employment } \\
\hline Basic Salary & $\begin{array}{l}\text { Permanent } \\
\text { ofinimum wage } \\
\text { of employee } \\
\text { Allowance for } \\
\text { duration of work }\end{array}$ & $\begin{array}{l}\text { Outsourced } \\
\text { Minimum } \\
\text { wage of } \\
\text { employee } \\
\text { Allowance } \\
\text { for } \\
\text { duration of } \\
\text { work }\end{array}$ \\
\hline $\begin{array}{l}\text { Premium presence } \\
\text { Insurance for workplace }\end{array}$ & Yes & No \\
\hline $\begin{array}{l}\text { Payment for food and } \\
\text { transportation }\end{array}$ & Yes & Yes \\
\hline Right for rest and leave & Yes & No \\
\hline Allowance for feast day & Yes & Yes \\
\hline Severance pay & Yes & Yes \\
\hline $\begin{array}{l}\text { Social security for employees } \\
\text { (Jamsostek) }\end{array}$ & Yes & Yes \\
\hline
\end{tabular}

Source: Ministerial Regulation Number 19 of 2012, processed by Author, 2017. 
As from table above, it seen that the outsourcing workers have less rights and get less pay in comparison with permanent workers, even with the exact amount of job burden. Based on the basic principle of labour law, the status of workers should not affect the rights they enjoy. ${ }^{37}$ However, as per the global market logic, the outsourcing system is a tool for companies to achieve maximum efficiency.$^{38}$ One way to do that is by reducing the rights that should have been obtained by outsourced workers. Because of the unclear regulation that we have until today, it became clear that the outsourcing worker is indeed receive different rights and less protection, comparing to the permanent workers.

\section{Improving Outsourcing System in Indo- nesia}

Labour practitioners continuously remind that outsourcing provides a good solution for dynamic and fast moving businesses. Elimination of outsourcing will not solve the issue of improving the welfare of labourers; even worse, it may raise a new problem of unemployment. Thus, instead of abolishing outsourcing that could lead to the layoff of millions of workers, the government should improve the system so that the outsourced workers will be have more protection, and may enjoy rights at par with the permanent workers in user companies.

As stated earlier, unpopularity with the outsourcing system in Indonesia and most of the problems in this system stem from obscure regulations concerning outsourcing itself. Hence, the problems associated with outsourcing work in Indonesia can only be solved by fixing the regulations. But what need to be fixed?

First, principle of equal rights. Among the many issues surrounding the outsourcing system in Indonesia, the main problem is basically the inequality in rights acquired of outsourced workers as compared to their permanent counterparts in the user company. The demand by labour unions for the appointment of outsourced workers as permanent employees stems from the fact that the outsourced employees have less rights and receive less salary, even for the exact same weightage of job.

Article 9(2) Ministerial Regulation Number 19 of 2012 already stipulates that the 'outsourcing agreement should at least contain the rights and obligations of each party, and ensure the fulfilment of labour protection and working conditions of workers/labourers' ${ }^{39}$, and yet, there is no further explanation on what kind of labour protection and working conditions does the provision entail. This regulation also lacks the guarantee that outsourced workers will get equal labour protection and working conditions as the permanent workers in the user company.

Implementing the principle of equal treatment is vital to avoid the common stigma against outsourcing in Indonesia that outsourced workers are 'second-class workers'. If the regulation can guarantee that outsourced workers will have equal rights and protection at par with permanent employees, the demand by Indonesian labour unions to abolish outsourcing may diminish. Moreover, applying the principle of equal rights is in line with the basic principle of labour law which states that 'the status of workers should not affect the rights they receive'.

Other problems that exist in the Indonesian outsourcing system are associated with the lack of certainty concerning the use of outsourcing work. For instance, Law Number 13 of 2003 regulates that outsourced jobs must not be associated with the core business of a company. Article 66 (1) of this regulation states that 'workers from labour suppliers must not be utilized by employers to carry out their enterprises' main activities or activities that are directly related to the production process

\footnotetext{
37 See: International Labour Organization (ILO) Declaration on Fundamental Principles and Rights at Work, 1998. See also: International Labour Organization, Labour Legislation Guidelines, Chapter IV: The Elimination of Discrimination in Respect of Employment and Occupation. Indah Saptorini and Jafar Suryomenggolo, Op. cit., p. 13.

39 Article 9 (2) Ministerial Regulation Number 19 of 2012 concerning The Requirements of Outsourcing.
} 
except for auxiliary service activities or activities that are indirectly related to the production process'. Nevertheless, in reality, this provision is not enforceable because the regulation does not provide any explanation on what is meant by 'main activities or core activities of the businesses'. The user company as well as the subcontractor company interpret by themselves what can be categorized as core activities and what cannot. As a result, lot of outsourced workers are employed in the core activities or the production process of a company.

Therefore, our regulation needs to clarify the limitation use of outsource workers. By providing clear limitations for the use of outsourced workers, misinterpretation as appearing nowadays in Indonesia can be avoided. Such limitations may be included in the amendment of Indonesian outsourcing regulation.

Another improvement that need to be done is strengthen the role of labour union. In most countries, labour unions play an important role in organizing and fighting for the best interest of the workers. The central function of trade unions is to represent people at work, but they also have a wider role in protecting their interest. Owing to the unions' dual role as a societal force and as lobbying organisations, their activities are usually focused on issues that directly concern the interests of union members. Promoting job security, wage levels and working conditions, with particular emphasis on health and safety, basically represent the core interest of labour unions. ${ }^{40}$

In relation to outsourcing, labour unions are supposed to be one powerful tool for agency workers to protect their rights and fight for their interest. It is important for a outsourcing workers to be included in the labour union. However, there is no specific provision in our law that offers protection for outsourced workers who want to be part of labour unions. Consequently, the majority of outsourced workers do not even join the labour unions. Research conducted by Social Analysis Centre AKATIGA in 2012, shows that $75.1 \%$ members of labour unions are permanent workers, $24.9 \%$ contract workers, but none of the members are outsourced workers. ${ }^{41}$

Based on the research, there are several reasons why outsourced workers in Indonesia do not join labour unions. First, the short contract period renders membership in any work-related organization irrelevant, despite the fact that labour unions guarantee freedom of association. Companies that hire outsourced workers know that they will not be part of unions. Second, workers recruited by employment agencies cannot form a union at their place of work because their job placement is temporary and unstable. Third, even if they have the courage and the chance to join a union, contract workers are concerned that union membership might be seen as an act of dissent and would jeopardize their already fragile employment. ${ }^{42}$ Majority of the outsourced workers state that the reason for not joining labour unions is related to their temporary employment status and fear of losing their jobs. ${ }^{43}$

We need to solve this problem by giving protection in our law to assure that outsource workers can join labour union in peace. If the outsourcing regulation can give assurances that the outsourced workers who join labour unions will not be discriminated against and their working status will not be jeopardized, then it may encourage outsourced workers to join labour unions.

Besides improving the regulation on outsourcing, ensuring that this regulation can be well implemented and enforced is also important. In Indonesia, even though regulations regarding outsourcing have been established for a long time, the absence of sanctions is a shortage in

\footnotetext{
40 Bernd Heins, 2004, The Role of Labour Unions in the Process Towards Sustainable Consumption and Production, Final Report to the United Nations Environment Programme, Paris, p. 4

AKATIGA Research in Indrasari Tjandraningsih, et al., Op. cit., p. 52.

Benny Hari Juliawan, Op. cit., p. 45.

AKATIGA Research in Indrasari Tjandraningsih, et al., Op. cit., p. 52-55.

Referring to Law Number 13 of 2003 and Ministerial Regulation Number 19 of 2012.
} 
these provisions. ${ }^{44}$ Since there is no strict sanction provided by the law, enforcement of outsourcing regulation is less effective. For instance, there is a general lack of awareness on the part of the user companies concerning their obligations for using the outsourcing system. ${ }^{45}$

This condition is exacerbated by the fact that Indonesian authorities have very limited supervisory powers, particularly relating to taking action against companies that violate the rules. ${ }^{46}$ At present, the enforcement of outsourcing regulation is the responsibility of Regional Office of Manpower and Transmigration Department. The only thing that the authorities can do is to give 'warning memorandum.' In practice, the companies often ignore this, and the authorities cannot take any further action since there is no legal basis to do so.

To improve this, Indonesia should amend its regulation so the authorities concerned will have enough power to inspect any probable misconduct by an outsourcing agency or user company. Indonesian outsourcing regulation should also provide effective, proportionate, and dissuasive penalties, so it can have a deterrent effect on offenders.

\section{Conclusion}

Outsourcing system has become very popular in Indonesian labour system in the past decade because it answers the need of flexible labour markets. However, the workers and unions are always resistance towards this system because the current regulation makes it detrimental towards workers. The absence of equal rights is basically the root cause of the problems. The workers mainly resist the outsourcing system because the regulations do not provide enough protection for them. In fact, outsourced employees get fewer rights and receive less pay, even for the same job weightage. The condition is aggravated since Indonesia's outsourcing regulation does not provide for strict sanctions against user companies and subcontractor companies that violate the terms and condition of the outsourcing system. As a result, the enforcement of outsourcing regulation becomes less effective.

However, this research concludes that elimination of outsourcing will not solve the problems. Instead of abolishing outsourcing, which could lead to the new problem of unemployment, the government should improve its regulations so that outsourced workers have the same rights and protection as enjoyed by permanent workers. The main thing the writer recommends is implementing principle of equal rights into Indonesian outsourcing regulation. The principle of equal rights should guarantee that the outsourcing workers will get the same working and employment conditions as the permanent workers, including the duration of working time, overtime, breaks, rest periods, night work, holidays, and most importantly the pay/salary of outsourced workers. These workers should also have equal treatment in relation to protection of pregnant women and nursing mothers, and protection of children and young people at the workplace. The government should also ensure that the regulation can be well implemented by giving an effective sanction or any other enforcement mechanism.

However, the writer aware that applying this recommendation is not easy. To amend one regulation in Indonesia may take long time and a lot of effort. Also, there is possibility of resistance from the business stakeholder in Indonesia, especially from the user companies. As discussed earlier, in accordance with global market logic, the outsourcing system is a tool for companies to achieve maximum efficiency. ${ }^{47}$ On the other hand, implementing equal salary and equal treatment into outsourcing regulation may reduce that maximum efficiency. Hence, outsourcing may no longer be a cheaper option for the user company to use.

Nonetheless, the writer believes that the

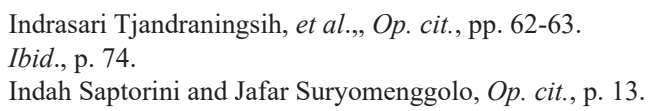


amendment of outsourcing regulation is visible as long as there is a strong will from the government. All of the stakeholders in the outsourcing business should keep in mind that based on the basic principle of labour law, the status of workers should not affect the rights they enjoy. Considering the fact that outsourcing has become a prominent tool to survive the economic challenges nowadays, the Indonesian government needs to guarantee that outsourced workers would get the rights and protection they deserve. Implementation of principle of equal rights will give better protection for outsourcing workers, reducing insecurities and removing uncertain legal condition surrounding outsourcing system.

\section{REFERENCES}

\section{A. Books}

Yasar, Iftida, 2012, Outsourcing Tidak Akan Pernah Bisa Dihapus, Pelita Fikir Indonesia, Jakarta. Saptorini, Indah and Jafar Suryomenggolo, 2007, Kekuatan Sosial Serikat Buruh: Putaran Baru dalam Perjuangan Menolak Outsourcing, Trade Union Rights Centre, Jakarta.

Tjandraningsih, Indrasari, et al., 2012, Diskriminatif and Eksploitatif: Praktek Kerja Kontrak dan Outsourcing Buruh di Sektor Industri Metal di Indonesia, AKATIGA, Bandung.

Herawati, Rina, 2010, Kontrak dan Outsourcing Harus Makin Diwaspadai, Yayasan AKATIGA, Jakarta.

\section{B. Internet}

Wanandi, Sofjan, “Global Business Guide Indonesia: Solutions for the Outsourcing System in Indonesia", http://www.gbgindonesia.com/ en/main/partners_updates/apindo/solutions_ for_the_outsourcing_system_in_indonesia. php, accessed on 5 October 2017.

\section{Journal Articles}

Juliawan, Benny Hari, "Extracting Labour From Its Owner: Private Employment Agencies and Labour Market Flexibility in Indonesia”, Critical Asian Studies, 26 Februari 2010.

\section{Research Report}

Hartman, Thomas, 2012, Temporary Agency Work in Germany and the Netherlands, Thesis, Tilburg University, Tilburg.

Heins, Bernd, 2004, The Role of Labour Unions in the Process Towards Sustainable Consumption and Production, Final Report to the United Nations Environment Programme, Paris.

\section{E. Regulations}

Law Number 13 of 2003 concerning Manpower Affairs (State Gazette of the Republic of Indonesia Number 39 Year 2003, Supplement to State Gazette of the Republic of Indonesia No. 4279).

Ministerial Regulation Number 19 of 2012 concerning The Requirements of Outsourcing. 